\title{
The Innovative Human Resource Management Framework: Impact of Green Competencies on Organisational Performance
}

\author{
Vuk Mirčetić ${ }^{1}$, Tatjana Ivanović ${ }^{1}$, Snežana Knežević ${ }^{1, *}$, Vesna Bogojević Arsić ${ }^{1}$, Tijana Obradović ${ }^{1}$, \\ Darjan Karabašević ${ }^{2}$, , Svetlana Vukotić ${ }^{2}$, Tomislav Brzaković ${ }^{2}$, Miljan Adamović ${ }^{3}$, Stefan Milojević ${ }^{4}$, \\ Marko Milašinović ${ }^{5}\left(0\right.$, , Aleksandra Mitrović ${ }^{5}\left(\right.$ and Marko Špiler ${ }^{1}(1)$
}

1 Faculty of Organizational Science, University of Belgrade, 11000 Belgrade, Serbia; info@vukmircetic.rs (V.M.); ivanovic.tatjana@fon.bg.ac.rs (T.I.); bogojevic-arsic.vesna@fon.bg.ac.rs (V.B.A.); tijana.obradovic@fon.bg.ac.rs (T.O.); mspiler@gmail.com (M.Š.)

2 Faculty of Applied Management, Economics and Finance, University Business Academy in Novi Sad, 21107 Novi Sad, Serbia; darjan.karabasevic@mef.edu.rs (D.K.); svetlana.vukotic@mef.edu.rs (S.V.); tomislav.brzakovic@mef.edu.rs (T.B.)

3 Pharmacy Institution "Zdravlje lek", 11000 Belgrade, Serbia; zdravljelek@gmail.com

4 Audit, Accounting, Financial and Consulting Service Company "MOODYS STANDARDS" Ltd., 11000 Belgrade, Serbia; aviation.adviser@gmail.com

5 Faculty of Hotel Management and Tourism in Vrnjačka Banja, University of Kragujevac, 36210 Vrnjačka Banja, Serbia; marko.milasinovic@kg.ac.rs (M.M.); aleksandra.stankovic@kg.ac.rs (A.M.)

* Correspondence: snezana.knezevic@fon.bg.ac.rs

check for updates

Citation: Mirčetić, V.; Ivanović, T.; Knežević, S.; Arsić, V.B.; Obradović,

T.; Karabašević, D.; Vukotić, S.;

Brzaković, T.; Adamović, M.

Milojević, S.; et al. The Innovative

Human Resource Management

Framework: Impact of Green

Competencies on Organisational

Performance. Sustainability 2022, 14,

2713. https://doi.org/10.3390/

su14052713

Academic Editor: Christian

Vandenberghe

Received: 7 February 2022

Accepted: 24 February 2022

Published: 25 February 2022

Publisher's Note: MDPI stays neutral with regard to jurisdictional claims in published maps and institutional affiliations.

Copyright: (C) 2022 by the authors. Licensee MDPI, Basel, Switzerland. This article is an open access article distributed under the terms and conditions of the Creative Commons Attribution (CC BY) license (https:// creativecommons.org/licenses/by/ $4.0 /)$.

\begin{abstract}
Scholars have emphasised the importance of green settings in today's business paradigms. Studies on green behaviour have produced a plethora of noteworthy discoveries, whether focused on financial success, individual capabilities, or development. However, despite significant growth in interest in green business practices, the relationship between individuals' willingness and green competencies has received little attention. This article used the customised green competencies conceptual model to investigate how green skills influence organisational performance and their relationship with the willingness moment. This article developed an innovative human resource management approach to address these difficulties. A questionnaire was used to perform empirical statistical research with 516 respondents from Serbian universities. Different mathematical and statistical methodologies were used to analyse the results. The findings corroborate the suggested theoretical model, and they suggest that green competencies will influence people's willingness to participate in green activities. This article gives new information on human behaviour and organisational effectiveness in a green atmosphere. It includes managerial and practical consequences and recommendations for businesses looking to improve their social responsibility and environmental sustainability.
\end{abstract}

Keywords: green performance; responsible innovations; sustainable HRM; green behaviour; financial performance; organisational growth; individual competencies

\section{Introduction}

Rapid development as a result of technology and scientific developments and many social, health, and financial crises in recent decades and worldwide trends have had a significant impact on business and the environment [1,2]. In today's global business climate, the only certainty is uncertainty. Many ongoing modern concerns have prompted changes in how organisations think about their objectives. Due to the ever-changing business environment in the age of globalisation, businesses face numerous challenges [3]. Recent difficulties and globalisation have a catalytic effect in all aspects of contemporary life and business [4], driving organisations to grow resiliently and sustainably. To preserve and acquire a competitive edge, organisations must adapt their business models to be more inclusive, pro-environmental, and innovative. Innovation for more significant influence 
entails developing innovative products or procedures to assist the organisations' beneficiaries and effectively address critical challenges [5]. The growing need for sustainable techniques can be seen in all industries [6], and there has recently been a slew of studies on sustainability and financial performance [7].

Bibi and Li [8] emphasized that numerous authors have indicated that implementing new legislation and economic policies will increase environmental efficiency. Rasche and Waddock [9] emphasise that numerous methods of industry regulations regarding the different trending aspects, including environmental protection, emerged in the last two decades. However, the future should be in incorporating sustainability for the sustainable and more resilient future, not only because of the legal obligations. Furthermore, the modern global business ecosystem triggered a new wave of corporate social responsibility activities that do not include only the regulatory requirement of the country [10-12]. Sustainability is a long-term goal [13], and it should be an integral part of every aspect of society. Organisations are becoming increasingly cognizant of the necessity to accomplish ethical, social, and environmental objectives [14].

In their research, Tornjanski and Čudanov [15] emphasised the need for organisational empowerment for a sustainable future. Environmentally concerned organisations must communicate their pro-environmental viewpoints to their personnel. Employees are an essential component of implementing pro-environmental procedures in businesses [16], and researchers $[17,18]$ point out that there has been a lot of research done on the impact of human capital on long-term development. Employees who integrate innovative processes and embrace new pro-environmental practices are more likely to achieve long-term goals [14]. Individuals are more engaged in goal-relevant activities [19]; as a result, organisations must embrace global environmental trends, incorporate sustainable goals into organisational objectives, and support individuals in becoming more environmentally conscious and helping others in this way, thereby constructing a new, more inclusive society.

A pro-environmentally conscious individual with green abilities and a commitment to help the environment and others comprehend and embrace modern difficulties and work on creative methods to improve organisational performance is described as having a new viewpoint on the environment. Furthermore, ecologically conscious and willing individuals will direct their green performance toward long-term growth, innovation, and financial performance.

Several academics discussed green segments in a variety of theoretical disciplines. Green behaviour analyses have previously revealed many important conclusions. Despite the growing interest among academics in green corporate practices, there remains a considerable gap in the understudied relationship between personal willingness and green competencies. This study intends to address a gap in the literature by looking into the relationship between green competencies and willingness.

This article contributes to the literature by analysing, synthesising, and providing an extensive and comprehensive review of published studies in this area, empirically researching the relationship between green competencies and organisational performance, and identifying future research directions.

\section{Sustainability and Human Resource Management}

Past studies $[20,21]$ have highlighted that human activities are causing about twofifths of all environmental problems, but recently, it can be assumed that direct and indirect human impacts are even more significant than previously described. The challenges organisations face have made them shift their business paradigms towards resilient and sustainable development and growth.

Mandip [22] considers that sustainable development should fulfil today's needs without compromising the chances of future generations to meet their needs. Sustainability is a dynamic and evolving concept [23], usually associated with stable systems, and it is of primary importance to organisations [24]. Zaugg [25] emphasises that employees, companies, and society should benefit from sustainability. It should be seen as a possibility to enhance 
competitiveness [26,27]. There are three dimensions of sustainability [28]: protection of the natural environment, maintenance of economic vitality, and observance of particular social considerations about human development, which is the most important for this study. Human resource management plays an essential role in implementing sustainable organisational practices with the aim of promoting environmental sustainability [29]. Additionally, incorporating sustainability into human resource management could bring humanity back to the management of human resources [30].

\subsection{Theoretical Background of Sustainable Human Resource Management}

Ehnert [31] noted the diversity of theoretical terminology explaining the relationship between sustainability and human resource management. For example, some authors use the term "sustainable human resource management" (e.g., [14,25,32]), others prefer "green human resource management" (e.g., [33]) and some emphasise the differences between these two terms. Vraňaková et al. [34] observe sustainability in the context of human resource management as twofold: supporting the implementation of a sustainable strategy and sustainable development, and sustainable work and sustainably performing human resource management.

Green human resource management offers a functional method for organisations to develop human capital and enhance their green performance and sustainable development [35-38]. Jabbour [39] supports the opinion that green human resource management practices positively influence organisations' green performance through various activities, while Kramar [40] defines it as human resource management activities with positive environmental results. In addition, some authors [41] consider it part of environmental management, and many authors [42,43] agree that improving employees' green behaviour will enhance an organisation's performance based on willingness.

Piwowar-Sulej [44] points out that sustainability has recently become more influential in developing an approach to employees and refers to it as sustainable HRM. Ehnert [32] defines sustainable human resource management as "the pattern of planned or emerging human resource management strategies and practices intended to enable organisational goal achievement while simultaneously reproducing the HR base over a long-lasting calendar time and controlling for self-induced side and feedback effects of HR systems on the HR base and thus on the company itself". The function of sustainable management is to facilitate the development of employees and human resource management practices for today and to meet forthcoming needs [31]. Thom and Zaugg [45] consider it to comprise "those long-term oriented conceptual approaches and activities aimed at socially responsible and economically appropriate recruitment and selection, development, deployment, and downsizing of employees".

Building on the integrative model of strategic human resource management [46], Ehnert [32] developed a model of sustainable management.

Compared to prior sustainable human resource management models, this model concentrates on the origin of human resources, such as family, schools, and universities, and adds socio-economic drivers, such as demographic trends and social, political, and legislative systems. In addition, the model provides possible short-term and long-term effects of sustainable human resource management:

1. Individual: employee well-being, work-life balance, health, employability;

2. Social: viability of sources of human resources, quality of life, good employer brand;

3. Organisational: long-term supply of workforce, healthy employees.

There are key tensions and paradoxes between efficiency and substance-oriented rationality and between social responsibility and efficiency-oriented rationality.

\subsection{Conceptual Model of Green Competencies and Adapted Green Competencies}

Competencies have a considerable influence on career success [47-49]. Some authors [50-52] consider that competencies represent the behaviours and attitudes employees need to perform their assignments effectively. Personal characteristics and circumstances, 
behaviours, knowledge, skills, attitudes, values, and beliefs are some professional competencies [48].

Organisations should take a proactive and systematic approach to modern challenges and have a variety of green strategies to increase employees' pro-environment awareness and competencies [29]. In addition, individual attitudes and values are fundamental elements that influence green competencies [53,54].

Roberts [55] classified competencies into four categories: natural, acquired, adaptive, and performance. Cousins [56] adapted this competency framework to the green setting. Individuals who have developed green competencies remain motivated through performance measures and reward methods that provide green performance development possibilities [41,57]. Authors [58,59] conducted various studies considering employees' motivation factors in different working environments. Table 1 shows the definitions of different types of green competencies and performance.

Table 1. Definitions of constructs.

\begin{tabular}{ccc}
\hline Construct & \multicolumn{1}{c}{ Definition } & Source \\
\hline Natural green competencies & $\begin{array}{c}\text { An individual's underlying traits and } \\
\text { personality dimensions, derived from } \\
\text { observations and mentoring received at } \\
\text { formative stages, regarding dominant } \\
\text { green behaviour of their immediate } \\
\text { social groups. }\end{array}$ & {$[55,60,61]$} \\
\hline Acquired green competencies & $\begin{array}{c}\text { Green knowledge and skills that an } \\
\text { individual accumulates through } \\
\text { experience regarding environmental } \\
\text { issues that lead to strong convictions } \\
\text { and feelings about acting in an } \\
\text { environmentally friendly manner. }\end{array}$ & {$[55,56,62]$} \\
\hline Effective green competencies & $\begin{array}{c}\text { Combination of natural and acquired } \\
\text { green competencies. }\end{array}$ & {$[55]$} \\
\hline Green performance & $\begin{array}{c}\text { Final output or observable behaviour } \\
\text { resulting from combination of natural, } \\
\text { acquired, and adaptive competencies. }\end{array}$ & {$[63-66]$} \\
\hline Source: [67] &
\end{tabular}

Natural green competencies (NGCs) are attributes and opinions formed in an individual's formative stages, while acquired green competencies (AGCs) represent green knowledge accumulated through experience. Pellegrini et al. [68] consider that employees' acquired green competencies support the integration of pro-environmental reasoning into the human resource activities of organisations. Combining natural and acquired green competencies produces effective green competencies essential for green performance.

Human resource management could benefit from measuring green behaviour to determine employees' green performance, which is the result of combined natural, acquired, and adaptive competencies. Someone can have green competencies, but it is also essential to want to help the environment to achieve green performance. Ivanović and Mirčetić [29] built on the green competencies conceptual model, and Subramanian et al. [67] introduced the willingness moment as a vital part of an individual's green performance and developed an adapted green competencies model (Figure 1).

As seen in the previous figure, both natural green competencies and acquired green competencies are prerequisites for effective green performance. The offered model is essential for this paper because it adds a new component to achieve green performance, the willing moment. For example, an individual can have excellent natural green competencies and advanced levels of acquired green competencies. However, Ivanović and Mirčetić [29] consider that green performance cannot be attained if an individual is unwilling to employ their effective green competencies, and because of that, the willingness moment is observed 
as an essential part of this model. The willingness moment can also predict an employee's attitude toward the environment or their ability to acquire green skills.

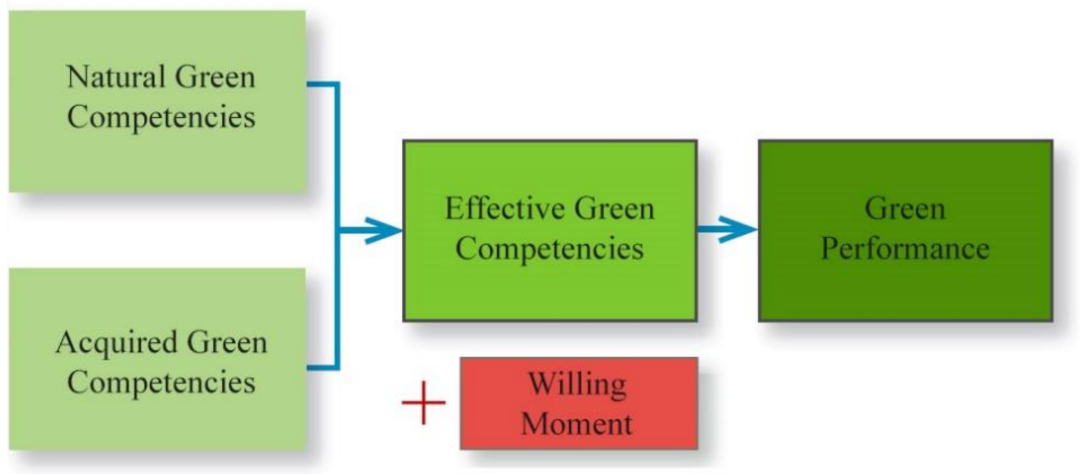

Figure 1. Adapted green competencies conceptual model. Source: [29].

\subsection{Impact of Pro-Environment Behaviour on Financial Performance}

Since the Industrial Revolution, finance has been a powerful enabler of human progress [69]. Levine [70] highlights finance as a key element in economic development. Finance represents a diverse ecosystem, with a function that can appear complex and opaque in the broader economy and the environment [71]. Noh [72] considers green finance as future-oriented, aiming to develop the financial industry, improve the environment, and enhance economic growth. Despite the importance of green finance and the significant increase in the number of scholars using this and similar terms, there is still no single agreed-upon definition that clearly explains it [72]. Independent of the differences in terminology in the literature, modern observation of finance has to be more inclusive and include pro-environment behaviour because it has direct and indirect implications for financial performance.

There is a significant interdependence between green behaviour and the financial performance of organisations. Recently, the green setting has been more visible in all business segments, and more organisations are shifting their business paradigms towards pro-environment and responsible activities. Environmental sustainability can have diverse impacts on organisational competitiveness [73,74]. Many scholars [75-77] have examined environmental performance in sustainable organisations and the relationship between environmental management and financial performance. Numerous studies have been conducted examining the impact of pro-environment human resource management activities on the green performance or organisations [78,79].

Sustainability has become a vital segment in many types of organisations. Petrović et al. [80] emphasised that scholars endeavour to define the term "sustainable entrepreneurship", which incorporates business, economic, ecological, and social aspects, while Aničić et al. [81] consider small and medium enterprises the carriers of development and innovative activities. Noh [82] points out that green growth provides both economic development and environmental enhancement. Rakić and Mitić [83] emphasise that green finance should include new technologies, financial products, industries, and services to support green growth.

As possible motives for the increased importance of green finance recently, Noh [82] considers increased risk due to environmental destruction and the insufficiency of natural resources, and the fact that the seriousness of the problem has been exaggerated, so stakeholders demand social responsibility. However, Schillebeeckx et al. [83] point out that organisations not only react to stakeholder preferences, but also consider how their reactions may affect the organisation's ability to create value. Organisations and stakeholders working together to add value in sustainable and mutually desirable ways leads to responsible innovation $[84,85]$, which is crucial to address contemporary challenges and achieve desired financial performance. 


\subsection{Theoretical Research Model}

For this research, a theoretical research model was created. The initial model (Figure 2) consisted of a dependent variable, green performance, and an independent variable, relationship to natural and acquired green competencies.

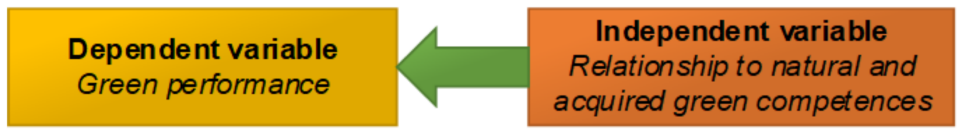

Figure 2. Theoretical research model. Source: Authors.

Further elaboration of the initial model led to a new theoretical research model (Figure 3), consisting of three independent variables, attitude towards the environment, natural green competencies, and acquired green competencies, and a dependent variable, willingness. Lorincová et al. [86] point out that corporate culture firmly contributes to the employees' willingness to achieve the organisation's objectives.

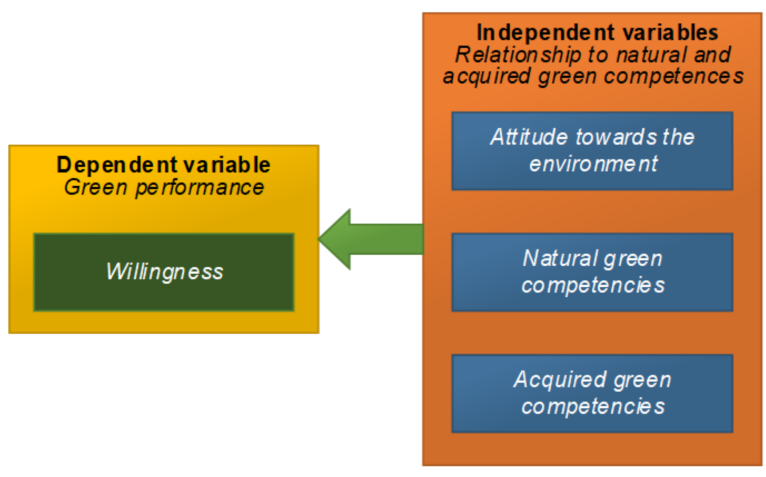

Figure 3. New theoretical research model. Source: Authors.

\subsection{Hypotheses}

Based on the new theoretical model, the following research sub-models with relationships between independent variables and dependent variable were developed, which also propose hypotheses as follows:

(a) Willingness sub-model in attitude towards the environment function (Figure 4), which proposes hypothesis H1: Attitude towards the environment affects willingness.

(b) Willingness sub-model in natural green competencies function (Figure 5), which proposes hypothesis $\mathrm{H} 2$ : Green competencies affect willingness.

(c) Willingness sub-model in acquired green competencies function (Figure 6), which proposes hypothesis H3: Acquired green competencies affect willingness.

(d) Multiple willingness sub-models in attitude towards the environment, natural green competencies and acquired green competencies functions (Figure 7), which propose general hypothesis $\mathrm{H} 0$ : Attitude towards the environment, natural green competencies, and acquired green competencies affect willingness.

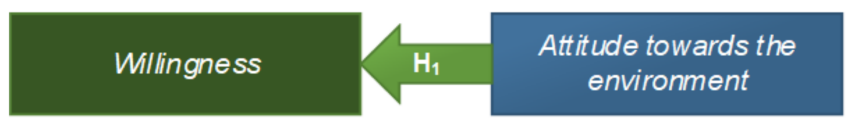

Figure 4. Willingness sub-model in attitude towards the environment function. Source: Authors.

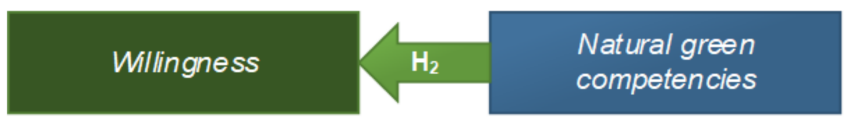

Figure 5. Willingness sub-model in natural green competencies function. Source: Authors. 


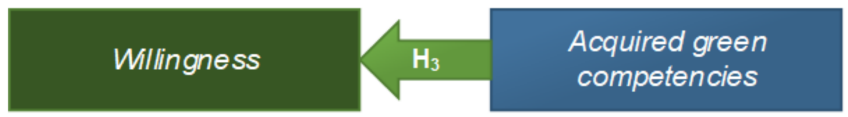

Figure 6. Willingness sub-model in acquired green competencies function. Source: Authors.

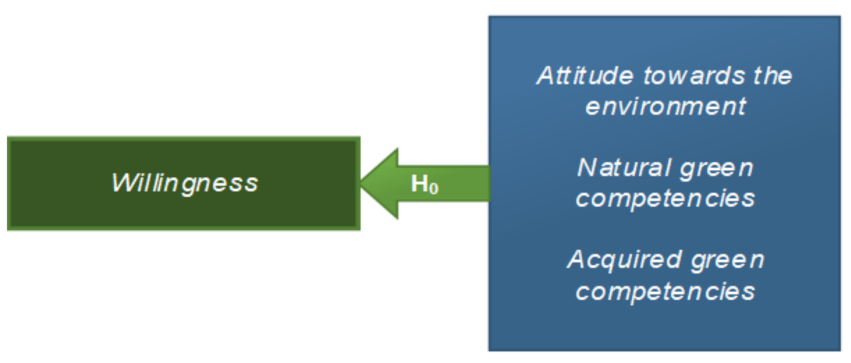

Figure 7. Multiple willingness model. Source: Authors.

\section{Materials and Methods}

In order to examine green competencies, the willingness moment, and their interdependency, empirical research was conducted with students, under the assumption that the activities of university studies are similar to those of employees $[87,88]$. The online questionnaire was distributed among students at universities in Serbia in October 2020.

In the empirical part of the paper, the survey method was used with a questionnaire. The results obtained by empirical statistical research were processed by the following mathematical and statistical methods: Cronbach's alpha coefficient, descriptive statistics, correlation and regression analysis, ANOVA, linear regression, and multiple linear correlation. The collected data were analysed using SAS JMP v.14 statistical software and were processed and presented textually, tabularly, and graphically.

The questionnaire on attitudes towards the environment and green competencies was designed in September 2020 and carried out in October 2020. It was formed by combining existing questionnaires on in-role and extra-role behaviour [89] and natural and acquired green competences [55].

The survey was structured in five major sections. The first part focused on the respondents' demographic profile. In the other four segments, respondents were asked to indicate how often they engage in specific pro-environment behaviours on a 5-point Likert scale ( $1=$ never, 5 = always). One segment related to in-role and extra-role green behaviours (4 items), which was measured by a scale adapted from Bissing-Olson et al. [89], with 2 items for each type of behaviour. Three parts were measured by a scale adapted from Roberts [55], and covered attitudes towards the environment (4 items), natural green competences (5 items) and acquired green competencies ( 5 items). The instrument was pilot tested for reliability of the research statements and variables.

A total of 516 respondents formed the sample for the research, 342 women $(66.3 \%)$ and 174 men (33.7\%), students at universities in Serbia. The majority of respondents were born between 1999 and 2001. A main finding of the research shows that characteristics of respondents can also be observed through their daily activities. For example, 78.4\% of respondents said they carry out their daily activities in an environmentally friendly way. In addition, most respondents (83.5\%) agreed that they carry out their study-related activities in a manner that does not harm the environment. On the other hand, only $25.1 \%$ of respondents said they were actively involved in environmental protection outside of their job, while $64.8 \%$ said they took the initiative often or always to perform their daily activities in an environmentally friendly manner. The results of analysing students green behaviour in terms of in-role and extra-role green behaviour revealed a difference in students' green behaviour, with more students engaging in in-role green behaviour than extra-role green behaviour. The research findings are in accordance with the findings of Bissing-Olson et al. [89] and Zhang et al. [90], implying that students are less likely to engage in proactive environmental conservation than adults. 
In terms of natural green competencies, $61.2 \%$ of respondents said their parents had stressed the importance of environmental protection during their childhood; $65.8 \%$ said they had listened to a lot about the importance of environmental protection during their childhood; $43.8 \%$ said they frequently watched educational programs about environmental protection or read/listened about the issue while growing up. In addition, 39.3\% of respondents said that their friends impacted their attitudes toward environmental protection in a favourable way, while $38.75 \%$ said that their university colleagues cared about the environment and positively influenced their attitudes. In terms of acquired green competencies, $57.4 \%$ of respondents said their prior experience had a significant impact on their environmental knowledge and skills; $35.8 \%$ of respondents had courses in their previous education that provided them with knowledge about environmental protection, and $23.6 \%$ of respondents have actively studied environmental issues. Overall, $96.1 \%$ of respondents believe they must protect the environment, while $89.7 \%$ of respondents are disturbed when they witness someone or something polluting the environment.

Students' opinions regarding environmental conservation were used to investigate the willing moment. Regarding their environmental attitudes, $44.1 \%$ of respondents believe they took better care of the environment under the state of emergency than they did previously. On the other hand, fewer students, $42.2 \%$ of respondents, believe they are more environmentally conscious after the state of emergency than before it, and $43.85 \%$ believe that e-learning is more environmentally friendly than classroom learning. Finally, $92.2 \%$ of respondents believe it is critical to protect the environment when conducting business.

Based on the recommendations for identifying factor limitations, the obtained Cronbach's alpha coefficient should be higher than recommended or $\geq 0.6$ [91]. Based on the rules and guidelines of internal consistency, the obtained value should be within $0.6 \leq \alpha \leq 1.0$ because this represents acceptable consistency, thus reliability of the research sample. In this research, all Cronbach's coefficients were acceptable for all set statements (Table 2) and variables (Table 3).

Table 2. Reliability of research statements.

\begin{tabular}{|c|c|c|}
\hline Statement & Cronbach's Coefficient & Reliability \\
\hline WILL 1 & 0.84 & $(0.7 \leq \alpha<0.9)$ sample is remarkably reliable. \\
\hline WILL 2 & 0.83 & $(0.7 \leq \alpha<0.9)$ sample is remarkably reliable. \\
\hline WILL 3 & 0.82 & $(0.7 \leq \alpha<0.9)$ sample is remarkably reliable. \\
\hline WILL 4 & 0.82 & $(0.7 \leq \alpha<0.9)$ sample is remarkably reliable. \\
\hline ATT 1 & 0.84 & $(0.7 \leq \alpha<0.9)$ sample is remarkably reliable. \\
\hline ATT 2 & 0.84 & $(0.7 \leq \alpha<0.9)$ sample is remarkably reliable. \\
\hline ATT 3 & 0.85 & $(0.7 \leq \alpha<0.9)$ sample is remarkably reliable. \\
\hline ATT 4 & 0.83 & $(0.7 \leq \alpha<0.9)$ sample is remarkably reliable. \\
\hline NGC 1 & 0.83 & $(0.7 \leq \alpha<0.9)$ sample is remarkably reliable. \\
\hline NGC 2 & 0.82 & $(0.7 \leq \alpha<0.9)$ sample is remarkably reliable. \\
\hline NGC 3 & 0.83 & $(0.7 \leq \alpha<0.9)$ sample is remarkably reliable. \\
\hline NGC 4 & 0.83 & $(0.7 \leq \alpha<0.9)$ sample is remarkably reliable. \\
\hline NGC 5 & 0.83 & $(0.7 \leq \alpha<0.9)$ sample is remarkably reliable. \\
\hline AGC 1 & 0.83 & $(0.7 \leq \alpha<0.9)$ sample is remarkably reliable. \\
\hline AGC 2 & 0.83 & $(0.7 \leq \alpha<0.9)$ sample is remarkably reliable. \\
\hline AGC 3 & 0.83 & $(0.7 \leq \alpha<0.9)$ sample is remarkably reliable. \\
\hline AGC 4 & 0.83 & $(0.7 \leq \alpha<0.9)$ sample is remarkably reliable. \\
\hline AGC 5 & 0.83 & $(0.7 \leq \alpha<0.9)$ sample is remarkably reliable. \\
\hline
\end{tabular}

Source: Authors. 
Table 3. Reliability of variables.

\begin{tabular}{ccc}
\hline Variable & Cronbach's Coefficient & Reliability \\
\hline Willingness & 0.66 & $(0.6 \leq \alpha<0.7)$ sample is reasonably reliable. \\
\hline $\begin{array}{c}\text { Attitude towards } \\
\text { environment }\end{array}$ & 0.79 & $(0.7 \leq \alpha<0.9)$ sample is remarkably reliable. \\
\hline $\begin{array}{c}\text { Natural green } \\
\text { competencies }\end{array}$ & 0.64 & $(0.6 \leq \alpha<0.7)$ sample is reasonably reliable. \\
\hline $\begin{array}{c}\text { Acquired green } \\
\text { competencies }\end{array}$ & 0.60 & $(0.6 \leq \alpha<0.7)$ sample is reasonably reliable. \\
\hline
\end{tabular}

Source: Authors.

Tables 2 and 3 show that the sample was reasonably reliable, therefore the questionnaire had acceptable construction for this research.

\section{Results and Discussion}

\subsection{Descriptive Statistics of Statements}

In this section of the paper, the values of descriptive statistics of respondents' answers to the set statements for all variables are given separately as mean value and standard deviation. Table 4 shows the mean values of the estimates for the variables and their standard deviations.

Table 4. Descriptive statistics of variables.

\begin{tabular}{ccc}
\hline Variable & Mean & Std Dev \\
\hline Willingness moment & 3.7200772 & 0.6870397 \\
\hline Attitude towards environment & 3.4995174 & 0.7621516 \\
\hline Natural green competencies & 3.4664093 & 0.7463069 \\
\hline Acquired green competencies & 3.7181467 & 0.5979485 \\
\hline
\end{tabular}

Source: Authors.

The variable WILL has the highest mean value at 3.7200772 and the variable NGC has the lowest mean value at 3.4664093 . The variable ATT has the largest standard deviation at 0.7621516 and the variable AGC has the smallest standard deviation at 0.5979485.

The frequency and percentage of attitudes according to the ratings are given in Table A1 in the Appendix A. For example, AGC 4 was scored 5 by the most respondents $(386,74.5 \%)$ and AGC 3 was scored 5 by the fewest respondents $(26,5.0 \%)$. On the other hand, ATT 3 was scored 1 by the most respondents $(80,15.4 \%)$ and ATT 4 was scored 1 by the fewest respondents $(2,0.4 \%)$. Finally, WILL 3 was scored 3 by the most respondents $(208,40.2 \%)$, while AGC 4 was scored 3 by the fewest respondents $(17,3.3 \%)$.

\subsection{Correlation and Regression Analysis of the Model}

Figure 8 displays the values of Pearson's correlation. The directions of all possible relationships between variables are positive, which means there is a positive correlation between variables.

The highest correlation coefficient is between NGC and AGC, at 0.6577 , or medium strong. That means that NGC can explain AGC with 0.43256929 or $43.25 \%$. The lowest correlation coefficient is between WILL ATT, at 0.2530 , or relatively weak. That means that WILL can explain ATT with only 0.064009 or $6.4 \%$.

Based on the theoretical sub-models (Figures 4-6), estimates of the statistical significance of influences are given for single linear dependencies (Table 5): independent variables ATT, NGC, and AGC on dependent variable WILL (ANOVA and interpretations for Std Beta, RSquare (\%), component connections, hypotheses, and regression equations). 


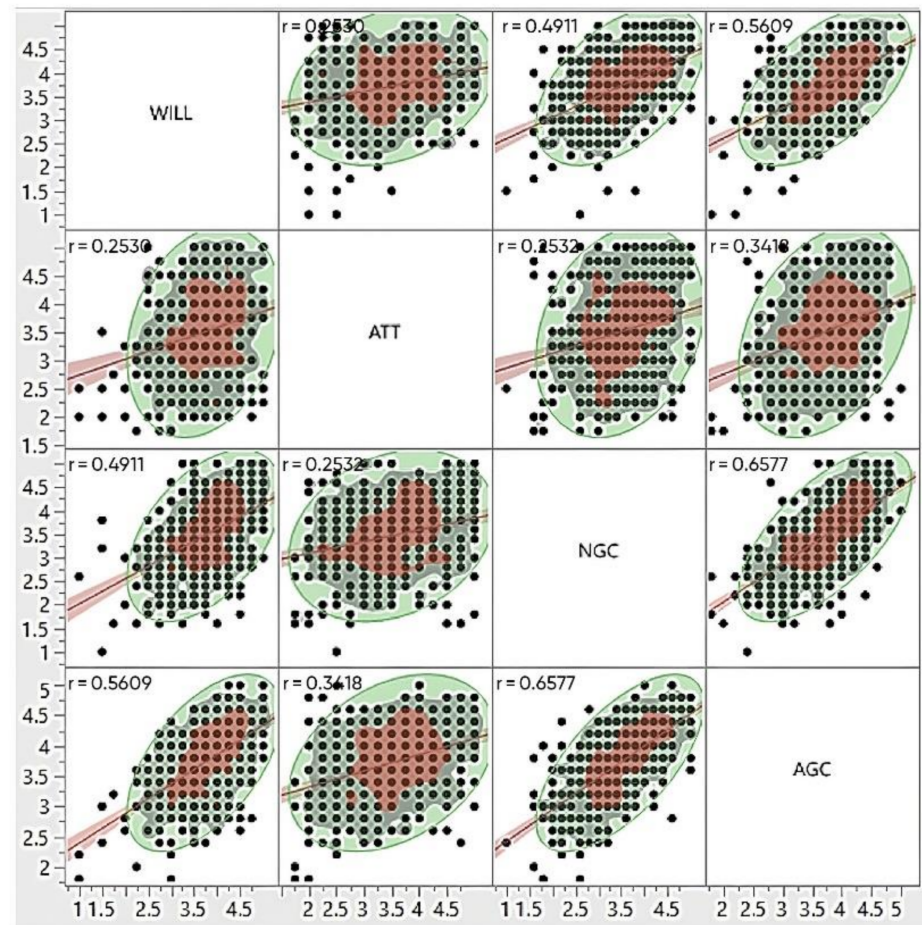

Figure 8. Correlation coefficients of set models. Source: Authors.

Table 5. Regression data for dependent variable WILL.

\begin{tabular}{|c|c|c|c|c|c|c|}
\hline $\begin{array}{l}\text { Independent } \\
\text { Variable }\end{array}$ & ANOVA & Std Beta & $\begin{array}{c}\text { RSquare } \\
(\%)\end{array}$ & Connectedness & Hypothesis & Regression Equation \\
\hline \multirow{2}{*}{$\begin{array}{c}\text { Attitude } \\
\text { towards } \\
\text { environment }\end{array}$} & $\begin{array}{c}\mathrm{F}(1516)=35.2889 \\
p<000001\end{array}$ & 0.3 & 6.4 & Relatively weak & $\begin{array}{l}\mathrm{H} 1 \text { is not } \\
\text { confirmed }\end{array}$ & $\begin{array}{c}\mathrm{y}=2.9219391+0.2280709 \cdot \mathrm{x} \_1 \\
\text { WILL }=2.9219391+0.2280709 \cdot \mathrm{ATT}\end{array}$ \\
\hline & Table A2 & \multicolumn{5}{|c|}{ Table A3 } \\
\hline \multirow{2}{*}{$\begin{array}{l}\text { Natural green } \\
\text { competencies }\end{array}$} & $\begin{array}{c}\mathrm{F}(1516)=163.9849 \\
p<0.0001\end{array}$ & 0.5 & 24.11 & Medium strong & $\begin{array}{l}\mathrm{H} 2 \text { is } \\
\text { confirmed }\end{array}$ & $\begin{array}{c}\mathrm{y}=2.152978+0.4520814 \cdot \mathrm{x} \_1 \\
\mathrm{WILL}=2.152978+0.4520814 \cdot \mathrm{NGC}\end{array}$ \\
\hline & Table A4 & \multicolumn{5}{|c|}{ Table A5 } \\
\hline \multirow{2}{*}{$\begin{array}{l}\text { Acquired green } \\
\text { competencies }\end{array}$} & $\begin{array}{c}\mathrm{F}(1516)=236.8614 \\
p<0.0001\end{array}$ & 0.6 & 31.46 & Medium strong & $\begin{array}{l}\mathrm{H} 3 \text { is } \\
\text { confirmed }\end{array}$ & $\begin{array}{c}\mathrm{y}=1.3238157+0.6444774 \cdot \mathrm{x} \_1 \\
\mathrm{WILL}=1.3238157+0.6444774 \cdot \mathrm{AGC}\end{array}$ \\
\hline & Table A6 & \multicolumn{5}{|c|}{ Table A7 } \\
\hline
\end{tabular}

Source: Authors.

Based on Figures 4-6 and Tables A2-A7 in the Appendix A, graphs of three single linear regression equations for WILL as a function of the variables were projected: attitude towards the environment, natural green competencies, and acquired green competencies (Figure 9).

Hypothesis H1, which states that ATT affects WILL, is not confirmed. Hypothesis $\mathrm{H} 2$ is confirmed, implying that NGC affects WILL. Hypothesis H3 is confirmed, indicating that AGC affects WILL.

Estimates, of the statistical significance of the influence of independent components ATT, NGC and AGC on dependent component WILL for multiple linear dependency (ANOVA and interpretations of Std Beta, RSquare (\%), component connections, hypothesis, and multiple regression equation) are given in Table 6. The obtained data (Tables A8 and A9 in the Appendix A) show that the contributions of the independent variables differ in multiple linear regression. 


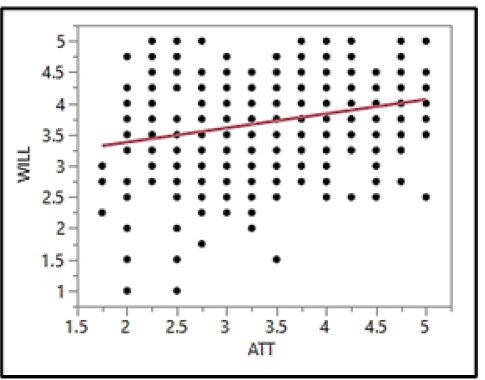

(a)

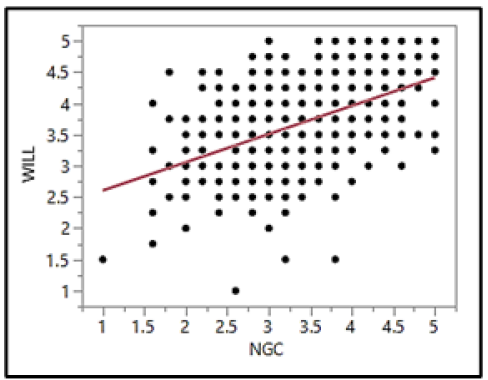

(b)

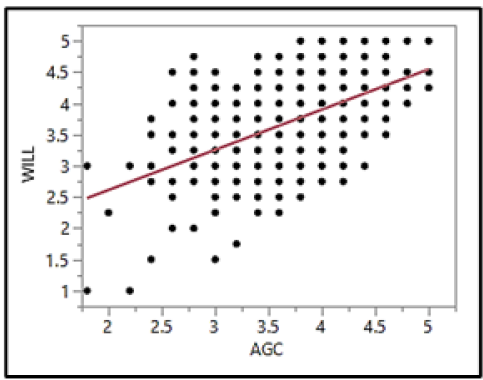

(c)

Figure 9. Graphs of single linear regression equations for willingness function of components: (a) attitude towards environment, (b) natural green competencies, and (c) acquired green competencies. Source: Authors.

Table 6. Multiple regression analysis data for dependent variable WILL.

\begin{tabular}{|c|c|c|c|c|c|c|}
\hline $\begin{array}{l}\text { Independent } \\
\text { Variables }\end{array}$ & ANOVA & Std Beta & RSquare (\%) & Connectedness & Hypothesis & Regression Equation \\
\hline \multirow[t]{2}{*}{$\begin{array}{c}\text { ATT, NGC and } \\
\text { AGC }\end{array}$} & $\begin{array}{c}\mathrm{F}(3514)=89.9948 \\
p<0.0001\end{array}$ & 0.6 & 34.43 & Medium-strong & $\begin{array}{l}\text { H0 is } \\
\text { confirmed }\end{array}$ & $\begin{array}{c}\mathrm{y}=1.1368655+0.056402 \cdot \mathrm{x} \_1 \\
+0.1953311 \cdot \mathrm{x} \_2+0.4595662 \cdot \mathrm{x} \_3 \\
\quad \text { WILL }=1.1368655 \\
+0.056402 \cdot \mathrm{ATT} \\
+0.1953311 \cdot \mathrm{NGC} \\
+0.4595662 \cdot \mathrm{AGC}\end{array}$ \\
\hline & Table A8 & \multicolumn{5}{|c|}{ Table A9 } \\
\hline
\end{tabular}

The most significant contribution to the dependent variable WILL is the independent variable AGC (39.99\%), followed by NGC (21.21\%) and ATT (6.25\%). Therefore, the general hypothesis $\mathrm{H0}$ is confirmed, indicating that ATT, NGC, and AGC affect WILL. The graph of the multiple linear regression equation of WILL as a function of ATT, NGC, and AGC shown in Figure 10 was projected based on Table 4.

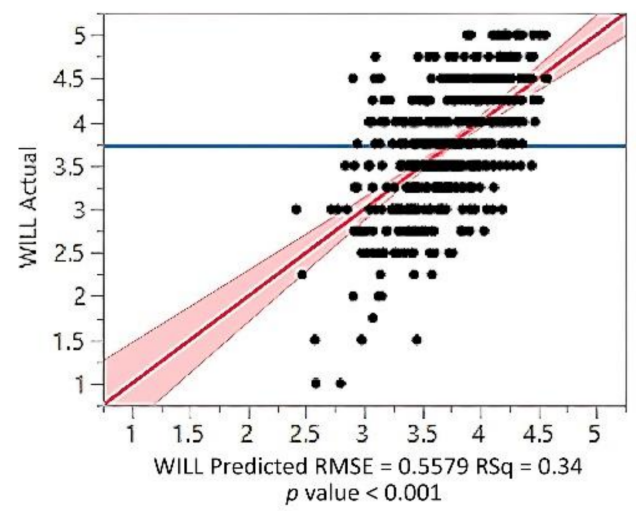

Figure 10. Graph of multiple linear regression equation of WILL as a function of ATT, NGC and AGC components. Source: Authors.

Based on the presented results, the multiple regression equation can be fitted, which means that the independent variable ATT can be excluded from the analysis, because its influence on the dependent variable WILL is insignificant for further research. Consequently, a new hypothesis H01 is set, showing that NGC and AGC affect WILL.

Table 7 shows the statistical significance of the influence of independent components NGC and AGC on the dependent component WILL for multiple linear dependence (ANOVA and interpretations of Std Beta, RSquare (\%), component connectivity, hypothesis, and multiple regression equation). 
Table 7. Multiple regression analysis data for dependent variable WILL.

\begin{tabular}{|c|c|c|c|c|c|c|}
\hline $\begin{array}{c}\text { Independent } \\
\text { Variables }\end{array}$ & ANOVA & Std Beta & RSquare (\%) & Connectedness & Hypothesis & Regression Equation \\
\hline \multirow[t]{2}{*}{ NGC and AGC } & $\begin{array}{c}\mathrm{F}(2515)=133.1978 \\
p<0.0001\end{array}$ & 0.6 & 34.09 & Medium strong & $\begin{array}{l}\text { H01 is } \\
\text { confirmed }\end{array}$ & $\begin{array}{c}\mathrm{y}=1.2416889 \\
+0.1982178 \cdot x \_2+0.4817681 \cdot \mathrm{x} \_3 \\
\text { WILL }=1.2416889 \\
+0.1982178 \cdot \mathrm{NGC} \\
+0.4817681 \cdot \text { AGC }\end{array}$ \\
\hline & Table A10 & \multicolumn{5}{|c|}{ Table A11 } \\
\hline
\end{tabular}

Based on the obtained data (Tables A10 and A11 in the Appendix A), it can be seen that the contributions of the independent variables differ in the multiple linear regression equation. The independent variable AGC makes the largest contribution to the dependent variable WILL (41.92\%), followed by NGC (21.53\%). The total coefficient of multiple determination is 0.340923 . Related to the previous multiple regression equation that included independent variable ATT, the total ratio decreased by only 0.003 , which is insignificant. Therefore, hypothesis H01 is accepted, meaning that NGC and AGC affect WILL.

Based on the obtained data considering hypothesis H01 (Table 4), a graph of the multiple linear regression equation of WILL as a function of NGC and AGC was projected (Figure 11).

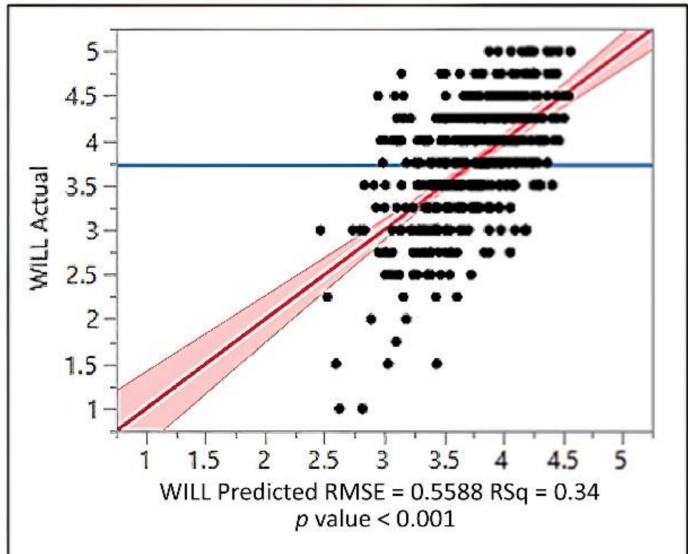

Figure 11. Graph of multiple linear regression equation of WILL as a function of NGC and AGC components. Source: Authors.

Based on the presented research, it can be concluded that the dependent component WILL can be explained by the independent component ATT with $6.4 \%$. Therefore, hypothesis H1, which states that ATT affects WILL, is not confirmed. The dependent component WILL can be explained by the independent component NGC with $24.11 \%$. Consequently, hypothesis $\mathrm{H} 2$ is confirmed, implying that NGC affects WILL. The dependent component WILL can be explained by the independent component AGC with $31.46 \%$. Accordingly, hypothesis $\mathrm{H} 3$ is confirmed, indicating that AGC affects WILL. The dependent component WILL can be explained by the independent components NGC, ATT, and AGC with $34.43 \%$. Therefore, hypothesis H0 is confirmed, meaning that NGC, ATT, and AGC affect WILL. Finally, the dependent component WILL can be explained by the independent components NGC and AGC with $34.09 \%$, implying that hypothesis H01 is confirmed and that NGC and AGC affect WILL.

\section{Conclusions}

According to the findings, the aim of the paper was fulfilled. Natural green competencies, acquired green competencies, and attitudes toward green behaviour of an individual 
affect the willingness of the same individual. Furthermore, university students are involved in environmental protection, although their attitudes and understanding about environmental preservation vary. However, much more can be done to raise student understanding of this critical issue. In this regard, both students and universities should work harder to promote environmentally friendly behaviour and green competencies, leading to improved green performance.

Green settings have become an essential part of the contemporary business environments, and it forces organisations to shift business paradigms to be more inclusive, pro-environmental, and innovative to maintain and gain a competitive edge. Furthermore, every forward-thinking organisation should consider incorporating sustainability into its processes to build future growth strategies. Green competencies of individuals are an essential part of this process. This paper endeavoured to examine how organisational performance is influenced by green competencies and willingness of individuals, and their interdependence and mutual relations. As a result, it can be concluded that a more inclusive and pro-environmental approach will have direct and indirect impacts on organisational growth, financial performance, and the environment. Accordingly, it means that embracing modern pro-environmental trends and nurturing green competencies benefit organisations in many ways.

This study is not exempt from some limitations and should be addressed in future research. The survey was undertaken for the first time in this article, and in a particular context, during the specific conditions regarding the global health pandemic that could influence the final results. The COVID-19 pandemic has had a detrimental impact on many aspects of human existence [92], including human resource management [93]. The poll solely pertains to students from universities in Serbia. Even though this research benefits from getting crucial information about students' attitudes toward green behaviour, it is also a limitation because it is uncertain if findings can be applied to students of different nations. There are also certain limitations regarding setting up the theoretical model. Firstly, there is a time lag between acquiring green competencies and developing willingness, which can be a limitation. Moreover, causation should be observed carefully because there can be collinearity if the analysis is observed only cross-sectionally.

Accordingly, these limitations give recommendations for future research paths. Future research can be undertaken after the COVID-19 pandemic to determine the impact of the pandemic on the results. The same survey should be undertaken in other countries to make a comparative analysis. The recommendation is to conduct the same research periodically to examine trends and make a comparative analysis. Finally, before the future research, scholars could set up a new theoretical model with stronger causation between variables.

The paper has practical, managerial, and theoretical implications. The main practical contributions are related to the new cognitions associated with green competencies impact on organisational performance. Managerial implications emerge from the need to observe the green environment differently by including pro-environmental and innovative premises, demonstrating the importance of a paradigm shift. The implied need to maintain and gain a competitive advantage necessitates considering the individual's green competencies and willingness. The article contributes to the existing literature providing a comprehensive literature review and, building on the existing theoretical model, adds willingness moment and proposes a new theoretical model. As a result, evaluating the impact of analysed parameters on performance can be considered a contribution of this paper and the Innovative Human Resource Management Framework can be used as a guideline for managers.

Author Contributions: V.M., T.I., S.K., T.O., D.K., S.V., T.B., M.A., S.M., M.M., A.M. and M.Š. carried out all stages of the study, including conceptualisation, methodology, analysis, writing-original draft preparation, and review and editing. V.B.A. was involved in conceptualisation and writing-original draft preparation and review and editing. All authors have read and agreed to the published version of the manuscript. 
Funding: This research received no external funding.

Institutional Review Board Statement: Not applicable.

Informed Consent Statement: Not applicable.

Data Availability Statement: Not applicable.

Conflicts of Interest: The authors declare no conflict of interest.

\section{Appendix A}

Table A1. Frequency and percentage of attitudes according to claims.

\begin{tabular}{|c|c|c|c|c|c|c|}
\hline \multicolumn{7}{|c|}{ Attitude } \\
\hline Claim & $1=$ Totally Disagree & 2 = Partially Disagree & $\begin{array}{c}3=\text { Neither Agree nor } \\
\text { Disagree }\end{array}$ & 4 = Partially Agree & $5=$ Totally Agree & Total \\
\hline WILL 1 & $\begin{array}{c}19 \\
3.7 \%\end{array}$ & $\begin{array}{c}20 \\
3.9 \%\end{array}$ & $\begin{array}{c}46 \\
8.9 \%\end{array}$ & $\begin{array}{c}165 \\
31.9 \%\end{array}$ & $\begin{array}{c}268 \\
517 \%\end{array}$ & \\
\hline WILL 2 & $\begin{array}{c}5 \\
1.0 \%\end{array}$ & $\begin{array}{c}17 \\
3.3 \%\end{array}$ & $\begin{array}{c}89 \\
17.2 \%\end{array}$ & $\begin{array}{c}280 \\
54.1 \%\end{array}$ & $\begin{array}{c}127 \\
24.5 \%\end{array}$ & \\
\hline WILL 3 & $\begin{array}{c}42 \\
8.1 \%\end{array}$ & $\begin{array}{c}138 \\
26.6 \%\end{array}$ & $\begin{array}{c}208 \\
40.2 \%\end{array}$ & $\begin{array}{c}100 \\
19.3 \%\end{array}$ & $\begin{array}{c}30 \\
5.8 \%\end{array}$ & \\
\hline WILL 4 & $\begin{array}{c}16 \\
3.1 \%\end{array}$ & $\begin{array}{c}34 \\
6.6 \%\end{array}$ & $\begin{array}{c}133 \\
25.7 \%\end{array}$ & $\begin{array}{c}200 \\
38.6 \%\end{array}$ & $\begin{array}{c}135 \\
26.1 \%\end{array}$ & \\
\hline ATT 1 & $\begin{array}{c}69 \\
13.3 \%\end{array}$ & $\begin{array}{c}92 \\
17.8 \%\end{array}$ & $\begin{array}{c}127 \\
24.5 \%\end{array}$ & $\begin{array}{c}142 \\
27.4 \%\end{array}$ & $\begin{array}{c}88 \\
17.0 \%\end{array}$ & \\
\hline ATT 2 & $\begin{array}{c}73 \\
14.1 \%\end{array}$ & $\begin{array}{c}93 \\
18.0 \%\end{array}$ & $\begin{array}{c}133 \\
25.7 \%\end{array}$ & $\begin{array}{c}131 \\
25.3 \%\end{array}$ & $\begin{array}{c}88 \\
17.0 \%\end{array}$ & \\
\hline ATT 3 & $\begin{array}{c}80 \\
15.4 \%\end{array}$ & $\begin{array}{c}73 \\
14.1 \%\end{array}$ & $\begin{array}{c}137 \\
26.4 \%\end{array}$ & $\begin{array}{c}140 \\
27.0 \%\end{array}$ & $\begin{array}{c}88 \\
17.0 \%\end{array}$ & \\
\hline ATT 4 & $\begin{array}{c}2 \\
0.4 \%\end{array}$ & $\begin{array}{c}3 \\
0.6 \%\end{array}$ & $\begin{array}{c}35 \\
6.8 \%\end{array}$ & $\begin{array}{c}153 \\
29.5 \%\end{array}$ & $\begin{array}{c}325 \\
62.7 \%\end{array}$ & \\
\hline NGC 1 & $\begin{array}{c}11 \\
2.1 \%\end{array}$ & $\begin{array}{c}49 \\
9.5 \%\end{array}$ & $\begin{array}{c}117 \\
22.6 \%\end{array}$ & $\begin{array}{c}169 \\
32.6 \%\end{array}$ & $\begin{array}{c}172 \\
33.2 \%\end{array}$ & 518 \\
\hline NGC 2 & $\begin{array}{c}18 \\
3.5 \%\end{array}$ & $\begin{array}{c}49 \\
9.5 \%\end{array}$ & $\begin{array}{c}133 \\
25.7 \%\end{array}$ & $\begin{array}{c}177 \\
34.2 \%\end{array}$ & $\begin{array}{c}141 \\
27.2 \%\end{array}$ & \\
\hline NGC 3 & $\begin{array}{c}26 \\
5.0 \%\end{array}$ & $\begin{array}{c}98 \\
18.9 \%\end{array}$ & $\begin{array}{c}168 \\
32.4 \%\end{array}$ & $\begin{array}{c}152 \\
29.3 \%\end{array}$ & $\begin{array}{c}74 \\
14.3 \%\end{array}$ & \\
\hline NGC 4 & $\begin{array}{c}27 \\
5.2 \%\end{array}$ & $\begin{array}{c}102 \\
19.7 \%\end{array}$ & $\begin{array}{c}185 \\
35.7 \%\end{array}$ & $\begin{array}{c}134 \\
25.9 \%\end{array}$ & $\begin{array}{c}70 \\
13.5 \%\end{array}$ & \\
\hline NGC 5 & $\begin{array}{c}21 \\
4.1 \%\end{array}$ & $\begin{array}{c}82 \\
15.8 \%\end{array}$ & $\begin{array}{c}215 \\
41.5 \%\end{array}$ & $\begin{array}{c}152 \\
29.3 \%\end{array}$ & $\begin{array}{c}48 \\
9.3 \%\end{array}$ & \\
\hline AGC 1 & $\begin{array}{c}8 \\
1.5 \%\end{array}$ & $\begin{array}{c}40 \\
7.7 \%\end{array}$ & $\begin{array}{c}172 \\
33.2 \%\end{array}$ & $\begin{array}{c}208 \\
40.2 \%\end{array}$ & $\begin{array}{c}90 \\
17.4 \%\end{array}$ & \\
\hline AGC 2 & $\begin{array}{c}36 \\
6.9 \%\end{array}$ & $\begin{array}{c}122 \\
23.6 \%\end{array}$ & $\begin{array}{c}175 \\
33.8 \%\end{array}$ & $\begin{array}{c}133 \\
25.7 \%\end{array}$ & $\begin{array}{c}52 \\
10.0 \%\end{array}$ & \\
\hline AGC 3 & $\begin{array}{c}77 \\
14.9 \% \\
\end{array}$ & $\begin{array}{c}156 \\
30.1 \%\end{array}$ & $\begin{array}{c}163 \\
31.5 \%\end{array}$ & $\begin{array}{c}96 \\
18.5 \%\end{array}$ & $\begin{array}{c}26 \\
5.0 \%\end{array}$ & \\
\hline AGC 4 & $\begin{array}{c}2 \\
0.4 \% \\
\end{array}$ & $\begin{array}{c}1 \\
0.2 \%\end{array}$ & $\begin{array}{c}17 \\
3.3 \% \\
\end{array}$ & $\begin{array}{c}112 \\
21.6 \% \\
\end{array}$ & $\begin{array}{c}386 \\
74.5 \% \\
\end{array}$ & \\
\hline AGC 5 & $\begin{array}{c}4 \\
0.8 \%\end{array}$ & $\begin{array}{c}7 \\
1.4 \%\end{array}$ & $\begin{array}{c}43 \\
8.3 \%\end{array}$ & $\begin{array}{c}145 \\
28.0 \%\end{array}$ & $\begin{array}{c}319 \\
61.6 \%\end{array}$ & \\
\hline
\end{tabular}


Table A2. ANOVA for WILL and ATT variables.

\begin{tabular}{ccccc}
\hline Source & DF & Sum of Squares & Mean Square & F Ratio \\
\hline Model & 1 & 15.62115 & 15.6212 & 35.2889 \\
\hline Error & 516 & 228.41505 & 0.4427 & Prob $>$ F \\
\hline C. Total & 517 & 244.03620 & & $<0.0001$ \\
\hline
\end{tabular}

Table A3. Coefficients for WILL and ATT variables.

\begin{tabular}{ccccccc}
\hline Term & Estimate & Std Error & $t$ Ratio & Prob $>|t|$ & Std Beta & VIF \\
\hline Intercept & 2.9219391 & 0.1375 & 21.25 & $<0.0001$ & 0 & \\
\hline ATT & 0.2280709 & 0.038393 & 5.94 & $<0.0001$ & 0.253005 & 1 \\
\hline
\end{tabular}

Table A4. ANOVA for WILL and NGT variables.

\begin{tabular}{ccccc}
\hline Source & DF & Sum of Squares & Mean Square & F Ratio \\
\hline Model & 1 & 58.85166 & 58.8517 & 163.9849 \\
\hline Error & 516 & 185.18453 & 0.3589 & Prob $>$ F \\
\hline C. Total & 517 & 244.03620 & & $<0.0001$ \\
\hline
\end{tabular}

Table A5. Coefficients for WILL and ATT variables.

\begin{tabular}{ccccccc}
\hline Term & Estimate & Std Error & $\boldsymbol{t}$ Ratio & Prob $>|t|$ & Std Beta & VIF \\
\hline Intercept & 2.152978 & 0.125174 & 17.20 & $<0.0001$ & 0 & \\
\hline NGC & 0.4520814 & 0.035303 & 12.81 & $<0.0001$ & 0.49108 & 1 \\
\hline
\end{tabular}

Table A6. ANOVA for WILL and NGT variables.

\begin{tabular}{ccccc}
\hline Source & DF & Sum of Squares & Mean Square & F Ratio \\
\hline Model & 1 & 76.77741 & 76.7774 & 236.8614 \\
\hline Error & 516 & 167.25878 & 0.3241 & Prob $>$ F \\
\hline C. Total & 517 & 244.03620 & & $<0.0001$ \\
\hline
\end{tabular}

Table A7. Coefficients for WILL and ATT variables.

\begin{tabular}{ccccccc}
\hline Term & Estimate & Std Error & $t$ Ratio & Prob $>|t|$ & Std Beta & VIF \\
\hline Intercept & 1.3238157 & 0.157696 & 8.39 & $<0.0001$ & 0 & \\
\hline AGC & 0.6444774 & 0.041876 & 15.39 & $<0.0001$ & 0.560905 & 1 \\
\hline
\end{tabular}

Table A8. ANOVA for WILL, ATT, NGT, and AGT variables.

\begin{tabular}{ccccc}
\hline Source & DF & Sum of Squares & Mean Square & F Ratio \\
\hline Model & 3 & 84.03989 & 28.0133 & 89.9948 \\
\hline Error & 514 & 159.99631 & 0.3113 & Prob $>$ F \\
\hline C. Total & 517 & 244.03620 & & $<0.0001$ \\
\hline
\end{tabular}


Table A9. Coefficients for WILL, ATT, NGT, and AGT variables.

\begin{tabular}{ccccccc}
\hline Term & Estimate & Std Error & $t$ Ratio & Prob $>|t|$ & Std Beta & VIF \\
\hline Intercept & 1.1368655 & 0.168131 & 6.76 & $<0.0001$ & 0 & \\
\hline ATT & 0.056402 & 0.034286 & 1.65 & 0.1006 & 0.062568 & 1.1341029 \\
\hline NGC & 0.1953311 & 0.043681 & 4.47 & $<0.0001$ & 0.212181 & 1.765106 \\
\hline AGC & 0.4595662 & 0.056122 & 8.19 & $<0.0001$ & 0.399972 & 1.8704231 \\
\hline
\end{tabular}

Table A10. ANOVA for WILL, NGT, and AGT variables.

\begin{tabular}{ccccc}
\hline Source & DF & Sum of Squares & Mean Square & F Ratio \\
\hline Model & 2 & 83.19750 & 41.5988 & 133.1978 \\
\hline Error & 515 & 160.83869 & 0.3123 & Prob $>$ F \\
\hline C. Total & 517 & 244.03620 & & $<0.0001$ \\
\hline
\end{tabular}

Table A11. Coefficients for WILL, NGT, and AGT variables.

\begin{tabular}{ccccccc}
\hline Term & Estimate & Std Error & $t$ Ratio & Prob $>|t|$ & Std Beta & VIF \\
\hline Intercept & 1.2416889 & 0.155846 & 7.97 & $<0.0001$ & 0 & \\
\hline NGC & 0.1982178 & 0.043718 & 4.53 & $<0.0001$ & 0.215317 & 1.7622575 \\
\hline AGC & 0.4817681 & 0.054565 & 8.83 & $<0.0001$ & 0.419295 & 1.7622575 \\
\hline
\end{tabular}

\section{References}

1. Popović, M. An MCDM approach for personnel selection using the CoCoSo method. J. Process Manag. New Technol. 2021, 9, 78-88. [CrossRef]

2. Đorđević, B. A process for assessing organization. J. Process Manag. New Technol. 2021, 9, 30-44. [CrossRef]

3. Pham, T.V.; Huang, Y.F.; Do, M.H. The Effect of Critical Work Factors on Job Motivation and Satisfaction: An Empirical Study from Vietnam. J. Asian Financ. Econ. Bus. 2022, 9, 399-408. [CrossRef]

4. Mirčetić, V.; Vukotić, S.; Cvijanović, D. The concept of business clusters and its impact on tourism business improvement. Econ. Agric. 2019, 66, 851-868. [CrossRef]

5. Ambos, T.C.; Tatarinov, K. Building Responsible Innovation in International Organizations through Intrapreneurship. J. Manag. Stud. 2022, 59, 92-125. [CrossRef]

6. Arsić, V.B.; Latinović, M.; Petrović, N. Sustainable switching option in green hotels construction. In Proceedings of the INBAM 2013-3rd Conference of the International Network of Business and Management Journals, Lisbon, Portugal, 13-17 June 2013.

7. Srebro, B.; Mavrenski, B.; Arsić, V.B.; Knežević, S.; Milašinović, M.; Travica, J. Bankruptcy Risk Prediction in Ensuring the Sustainable Operation of Agriculture Companies. Sustainability 2021, 13, 7712. [CrossRef]

8. Bibi, A.; Li, X.M. The asymmetric dilemma of renewable energy, financial development, and economic growth: Fresh evidence from Pakistan. Environ. Sci. Pollut. Res. Int. 2022, 1-10. [CrossRef]

9. Rasche, A.; Waddock, S. Standards for CSR: Legitimacy, impact and critique. In Corporate Social Responsibility: Strategy, Communication, Governance; Rasche, A., Morsing, M., Moon, J., Eds.; Cambridge University Press: Cambridge, UK, 2017 ; pp. $163-186$.

10. Bénabou, R.; Tirole, J. Individual and corporate social responsibility. Economica 2010, 77, 1-19. [CrossRef]

11. Kitzmueller, M.; Shimshack, J. Economic perspectives on corporate social responsibility. J. Econ. Lit. 2012, 50, 51-84. [CrossRef]

12. Akinyi, O.J.; Shem, M.; Joseph, K. The role of procurement procedures in environmental management: A case study of classified hotels in Mombasa County, Kenya. Hotel Tour. Manag. 2020, 8, 11-23. [CrossRef]

13. Dania, O.R.; Okobia, E.O. Staff awareness of the role of education in sustainable development goals, Evidence from the University of Benin. In Implementing the Sustainable Development Goals in Nigeria Barriers, Prospects and Strategies, 1st ed.; Ekhator, E.O., Miller, S., Igbinosa, E., Eds.; Routledge: London, UK, 2022.

14. Chams, N.; García-Blandón, J. On the importance of sustainable human resource management for the adoption of sustainable development goals. Resour. Conserv. Recycl. 2019, 141, 109-122. [CrossRef]

15. Tornjanski, V.; Čudanov, M. Towards Society 5.0 Era: Organisational Empowerment of the Sustainable Future. In Proceedings of the 3rd Virtual International Conference Path to a Knowledge Society-Managing Risks and Innovation, Complex System Research Centre, Niš and Mathematical Institute of the Serbian Academy of Sciences and Arts, Niš, Serbia, 15-16 November 2021; pp. 413-421.

16. Renwick, D.W.S. Contemporary Developments in Green Human Resource Management Research, Towards Sustainability in Action? Routledge: London, UK, 2020. 
17. Speth, J.G. American Passage: Towards a new economy and a new politics. Ecol. Econ. 2012, 84, 181-186. [CrossRef]

18. Pfeffer, J. Building sustainable organizations: The human factor. Acad. Manag. Perspect. 2010, 24, 34-45. [CrossRef]

19. Mitsuhashi, H.; Nakamura, A. Pay and networks in organizations: Incentive redesign as a driver of network change. Strateg. Manag. J. 2021, 43, 295-322. [CrossRef]

20. Grunert, S.C. Everybody seems concern about the environment: But is this concern reflected in (Danish) consumers' food choice? Eur. Adv. Consum. Res. 1993, 1, 428-433.

21. Gan, C.; Wee, H.Y.; Ozanne, L.; Kao, T.H. Consumers' purchasing behavior towards green products in New Zealand. Innov. Mark. 2008, 4, 93-102.

22. Mandip, G. Green HRM: People Management Commitment to Environmental Sustainability. Res. J. Recent Sci. 2012, 1, $244-252$.

23. Abeles, T.P. Is sustainability a viable concept for planning? Foresight 1999, 1, 265-273. [CrossRef]

24. Goyal, P.; Rahman, Z.; Kazmi, A.A. Identification and prioritization of corporate sustainability practices using analytical hierarchy process. J. Model. Manag. 2015, 10, 23-49. [CrossRef]

25. Zaugg, R.J. Nachhaltiges Personalmanagement: Eine Neue Perspektive und Empirische Exploration des Human Resource Management; Deutscher Universitätsverlag: Wiesbaden, Germany, 2009.

26. Hart, S.L. Innovation, creative destruction and sustainability. Res. Technol. Manag. 2005, 48, 21-27. [CrossRef]

27. Moneva, J.M.; Ortas, E. Corporate environmental and financial performance: A multivariate approach. Ind. Manag. Data Syst. 2010, 110, 193-210. [CrossRef]

28. DiGiulio, A. Education for sustainable development-What does it mean and what should students learn? In Higher Education for Sustainability; Adomssent, M., Godeman, J., Leicht, A., Busch, A., Eds.; VAS Publisher: Frankfurt, Germany, 2006 ; pp. 60-66.

29. Ivanović, T.; Mirčetić, V. Exploring students' attitudes towards green behavior. In Thematic Proceedings of the MEFkon 2020; MEF Faculty: Belgrade, Serbia, 2020; pp. 1-18.

30. De Prins, P.; Van Beirendonck, L.; De Vos, A.; Segers, J. Sustainable HRM: Bridging theory and practice through the 'Respect Openness Continuity (ROC)'-model. Manag. Revue. Socio-Econ. Stud. 2014, 25, 263-284. [CrossRef]

31. Ehnert, I. Sustainability and HRM: A Model and Suggestions for Future Research. In The Future of Employment Relations; Wilkinson, A., Townsend, K., Eds.; Palgrave Macmillan: London, UK, 2011; pp. 215-237.

32. Ehnert, I. Sustainable Human Resource Management: A Conceptual and Exploratory Analysis from a Paradox Perspective. Contributions to Management Science; Springer: Berlin/Heidelberg, Germany, 2009.

33. Renwick, D.W.S.; Redman, T.; Maguire, S. Green HRM: A Review, Process Model, and Research Agenda; Discussion Paper Series, No. 2008.01; University of Sheffield Management School: Sheffield, UK, 2008.

34. Vraňaková, N.; Gyurák Babel'ová, Z.; Chlpeková, A. Sustainable Human Resource Management and Generational Diversity: The Importance of the Age Management Pillars. Sustainability 2021, 13, 8496. [CrossRef]

35. Siebenhüner, B.; Arnold, M. Organizational learning to manage sustainable development. Bus. Strategy Environ. 2007, 16, 339-353. [CrossRef]

36. Wolf, J. Improving the sustainable development of firms: The role of employees. Bus. Strategy Environ. 2013, 22, 92-108. [CrossRef]

37. Jaramillo, J.Á.; Sossa, J.W.Z.; Mendoza, G.L.O. Barriers to sustainability for small and medium enterprises in the framework of sustainable development-Literature review. Bus. Strategy Environ. 2018, 28, 512-524. [CrossRef]

38. Wong, C.W.Y.; Wong, C.Y.; \& Boon-Itt, S. How does sustainable development of supply chains make firms lean, green and profitable? A resource orchestration perspective. Bus. Strategy Environ. 2018, 27, 375-388. [CrossRef]

39. Jabbour, C.J.C. Environmental training and environmental management maturity of Brazilian companies with ISO14001: Empirical evidence. J. Clean. Prod. 2015, 96, 331-338. [CrossRef]

40. Kramar, R. Beyond strategic human resource management: Is sustainable human resource management the next approach? Int. J. Hum. Resour. Manag. 2014, 25, 1069-1089. [CrossRef]

41. Renwick, D.W.S.; Redman, T.; Maguire, S. Green human resource management: A review and research agenda. Int. J. Manag. Rev. 2013, 15, 1-14. [CrossRef]

42. Kim, A.; Kim, Y.; Han, K.; Jackson, S.E.; Ployhart, R.E. Multilevel influences on voluntary workplace green behavior: Individual differences, leader behavior, and coworker advocacy. J. Manag. 2014, 43, 1335-1358. [CrossRef]

43. Pham, N.T.; Tučková, Z.; Jabbour, C.J.C. Greening the hospitality industry: How do green human resource management practices influence organizational citizenship behavior in hotels. Tour. Manag. 2019, 72, 386-399. [CrossRef]

44. Piwowar-Sulej, K. Human resources development as an element of sustainable HRM-With the focus on production engineers. J. Clean. Prod. 2021, 278, 124008. [CrossRef] [PubMed]

45. Thom, N.; Zaugg, R.J. Nachhaltiges und innovatives Personalmanagement: Spitzengruppenbefragung in europaeischen Unternehmungen und Institutionen. In Nachhaltiges Innovationsmanagement; Schwarz, E.J., Ed.; Gabler Verlag: Wiesbaden, Germany, 2004; pp. 215-245.

46. Martín-Alcázar, F.; Romero-Fernández, P.M.; Sánchez-Gardey, G. Strategic human resource management: Integrating the universalistic, contingent, configurational and contextual perspectives. Int. J. Hum. Resour. Manag. 2005, 16, 633-659. [CrossRef]

47. Birdir, K.; Pearson, T. Research chefs' competencies: A Delphi approach. Int. J. Contemp. Hosp. Manag. 2000, 12, 205-209. [CrossRef]

48. Jeou-Shyan, J.; Hsuan, H.; Chih-Hsing, C.; Lin, L.; Chang-Yen, C. Competency analysis of top managers in the Taiwanese hotel industry. Int. J. Hosp. Manag. 2011, 30, 1044-1054. [CrossRef] 
49. Ognjanović, J. Employer brand and workforce performance in hotel companies. Hotel. Tour. Manag. 2020, 8, 65-78. [CrossRef]

50. Wood, R.C. Working in Hotel and Catering, 2nd ed.; International Thomson Business Press: London, UK, 1997.

51. Brownell, J. Leading on land and sea: Competencies and context. Int. J. Hosp. Manag. 2008, 27, 137-150. [CrossRef]

52. Zopiatis, A. Is it art or science? Chef's competencies for success. Int. J. Hosp. Manag. 2010, 29, 459-467. [CrossRef]

53. Ramayah, T.; Lee, J.W.C.; Mohamad, O. Green product purchase intention: Some insights from a developing country. Resour. Conserv. Recycl. 2010, 54, 1419-1427. [CrossRef]

54. Zhao, H.-H.; Gao, Q.; Wu, Y.-P.; Wang, Y.; Zhu, X.-D. What affects green consumer behavior in China? A case study from Qingdao. J. Clean. Prod. 2014, 63, 143-151. [CrossRef]

55. Roberts, G. Recruitment and Selection: A Competency Approach; IPD: London, UK, 1997.

56. Cousins, P.D.; Lamming, R.C.; Lawson, B.; Squire, B. Strategic Supply Management: Theories, Concepts and Practice; Pearson Education Limited: Harlow, UK, 2008.

57. Attaianese, E. A broader consideration of human factor to enhance sustainable building design. Work 2012, 41, 2155-2159. [CrossRef] [PubMed]

58. Janovac, T.; Virijević Jovanović, S.; Tadić, J.; Tomić, G.; Ćulafić, S. The influence of employee motivation factors on job satisfaction in mining companies. Pol. J. Manag. Stud. 2021, 23, 224-238. [CrossRef]

59. Mureșan, G.M.; Fülöp, M.T.; Ciumaș, C. The Road from Money to Happiness. J. Risk Financ. Manag. 2021, 14, 459. [CrossRef]

60. Yeung, S.P. Teaching approaches in geography and students? Environmental attitudes. Environmentalist 2004, $24,101-117$. [CrossRef]

61. Kim, Y.; Choi, S.M. Antecedents of green purchase behavior: An examination of collectivism, environmental concern, and PCE. Adv. Consum. Res. 2005, 32, 592-599.

62. Fryxell, G.E.; Lo, C.W.H. The influence of environmental knowledge and values on managerial behaviors on behalf of the environment: An empirical examination of managers in China. J. Bus. Ethics 2003, 46, 45-69. [CrossRef]

63. Follows, S.B.; Jobber, D. Environmentally responsible purchase behaviour: A test of a consumer model. Eur. J. Mark. 2000, 34, 723-746. [CrossRef]

64. Tan, B.C. The role of perceived consumer effectiveness on value-attitude-behavior model in green buying behavior context. Aust. J. Basic Appl. Sci. 2011, 5, 1766-1771.

65. Mainieri, T.; Barnett, E.G.; Valdero, T.R.; Unipan, J.B.; Oskamp, S. Green buying: The influence of environmental concern on consumer behavior. J. Soc. Psychol. 1997, 137, 189-204. [CrossRef]

66. Kaufmann, H.R.; Panni, M.F.A.K.; Orphanidou, Y. Factors affecting consumers' green purchasing behavior: An integrated conceptual framework. Amfiteatru Econ. 2012, 14, 50-69.

67. Subramanian, N.; Abdulrahman, M.D.; Wu, L.; Nath, P. Green competence framework: Evidence from China. Int. J. Hum. Resour. Manag. 2016, 27, 151-172. [CrossRef]

68. Pellegrini, C.; Rizzi, F.; Frey, M. The role of sustainable human resource practices in influencing employee behavior for corporate sustainability. Bus. Strategy Environ. 2018, 27, 1221-1232. [CrossRef]

69. Sachs, J.; Woo, W.T.; Yoshino, N.; Taghizadeh-Hesary, F. Importance of Green Finance for Achieving Sustainable Development Goals and Energy Security. In Handbook of Green Finance; Sachs, J., Woo, W.T., Yoshino, N., Eds.; Springer: Singapore, 2019; pp. 3-12.

70. Levine, R. Financial development and economic growth: Views and agenda. J. Econ. Lit. 1997, 35, 688-726.

71. Bose, S.; Dong, G.; Simpson, A. The Financial Ecosystem, the Role of Finance in Achieving Sustainability; Palgrave Macmillan: Cham, Switzerland, 2019.

72. Noh, H.J. Financial Strategies to Accelerate Green Growth; ADBI Working Paper 866; Asian Development Bank Institute: Tokyo, Japan, 2019.

73. Busch, T.; Hoffmann, V.H. How hot is your bottom line? Linking carbon and financial performance. Bus. Soc. 2011, 50, 233-265. [CrossRef]

74. Zollo, M.; Cennamo, C.; Neumann, K. Beyond what and why: Understanding organizational evolution towards sustainable enterprise models. Organ. Environ. 2013, 26, 241-259. [CrossRef]

75. Porter, M.E.; van der Linde, C. Toward a new conception of the environment-competitiveness relationship. J. Econ. Perspect. 1995, 9, 97-118. [CrossRef]

76. Albertini, E. Does environmental management improve financial performance? A meta-analytical review. Organ. Environ. 2013, 26, 431-457. [CrossRef]

77. Ortas, E.; Moneva, J.M.; Álvarez, I. Sustainable supply chain and company performance: A global examination. Supply Chain Manag. 2014, 19, 332-350. [CrossRef]

78. Daily, B.F.; Bishop, J.W.; Massoud, J.A. The role of training and empowerment in environmental performance: A study of the Mexican maquiladora industry. Int. J. Oper. Prod. Manag. 2012, 32, 631-647. [CrossRef]

79. Arda, O.A.; Bayraktar, E.; Tatoglu, E. How do integrated quality and environmental management practices affect firm performance? Mediating roles of quality performance and environmental proactivity. Bus. Strategy Environ. 2018, $28,64-78$. [CrossRef]

80. Petrović, Ž.; Zakić, N.; Vukotić, S. Održivo preduzetništvo kao nosilac razvoja malih preduzeća u Srbiji. Ecologica 2018, 74, 186-190. 
81. Aničić, J.; Zakić, N.; Vukotić, S.; Subić, J. Clustering as an Opportunity for Internationalization of the SME Sector in Serbia. J. Balk. Near East. 2016, 18, 506-524. [CrossRef]

82. Noh, H.J. Green Finance; Park Young Sa: Seoul, Korea, 2012.

83. Schillebeeckx, S.J.D.; Kautonen, T.; Hakala, H. To Buy Green or Not to Buy Green: Do Structural Dependencies Block Ecological Responsiveness? J. Manag. 2020, 48, 472-501. [CrossRef]

84. Tihon, A.; Ingham, M. The societal system and responsible innovations: Freeing sustainable development from a deadlock. J. Innov. Econ. Manag. 2011, 2, 11-31. [CrossRef]

85. von Schomberg, R. Prospects for technology assessment in a framework of responsible research and innovation. In Technikfolgen Abschätzen Lehren; Dusseldorp, M., Beecroft, R., Eds.; VS Verlag für Sozialwissenschaften: Wiesbaden, Germany, $2012 ;$ pp. 39-61.

86. Lorincová, S.; Miklošík, A.; Hitka, M. The role of corporate culture in economic development of small and medium-sized enterprises. Technol. Econ. Dev. Econ. 2022, 28, 220-238. [CrossRef]

87. Salanova, M.; Schaufeli, W.; Martínez, I.; Bresó, E. How obstacles and facilitators predict academic performance: The mediating role of study burnout and engagement. Anxiety Stress Coping 2010, 23, 53-70. [CrossRef] [PubMed]

88. van Beek, I. Understanding the Dark and Bright Sides of Heavy Work Investment: Psychological Studies on Workaholism and Work Engagement. Ph.D. Thesis, Utrecht University, Utrecht, The Netherlands, 2014.

89. Bissing-Olson, M.J.; Fielding, K.S.; Iyer, A. Diary methods and workplace pro-environmental behaviors. In The Psychology of Green Organizations; Robertson, J.L., Barling, J., Eds.; Oxford University Press: New York, NY, USA, 2015; pp. 95-116.

90. Zhang, Y.; Luo, Y.; Zhang, X.; Zhao, J. How Green Human Resource Management Can Promote Green Employee Behavior in China: A Technology Acceptance Model Perspective. Sustainability 2019, 11, 5408. [CrossRef]

91. Nunnally, J.C. Psychometric Theory, 2nd ed.; McGraw-Hill: New York, NY, USA, 1978.

92. Milovanović, V.; Paunović, M.; Avramovski, S. The impact of COVID-19 on the hotel supply chain management. Hotel Tour. Manag. 2021, 9, 63-78. [CrossRef]

93. Hitka, M.; Štarchoň, P.; Caha, Z.; Lorincová, S.; Sedliačiková, M. The global health pandemic and its impact on the motivation of employees in micro and small enterprises: A case study in the Slovak Republic. Econ. Res.-Ekon. Istraživanja 2021, 1-21. [CrossRef] 